\title{
ANALISIS CSR DAN KINERJA KEUANGAN STUDI EMPIRIS PADA PERUSAHAAN YANG TERDAFTAR PADA INDEKS SRI KEHATI
}

\author{
Farah Margaretha (farahmargaretha@yahoo.com)
}

Universitas Trisakti

\begin{abstract}
The objectives of this study are to analyze the difference and correlation between the corporate social performance and the corporate financial performance Companies in Indonesia, The sample population of this study is company listed in Indonesian Stock Exchange. sampling was used in this study, are 23 companies in SRI KEHATI Index The CSR score is measured by content analysis of corporate annual report. The data is tested by using partial correlation test to know the correlation between the corporate social performance and financial performance. The results of this study show that there no significant relation between financial performance at (t) year and CSR but found significant at tht $(t+1)$ year. Managerial implications from this research will hopefully provide a new discourse for investor in considering the aspects that need to be taken into investments that are not to monetary measurements. this research hopes management company can provide the input on the importance of corporate social responsibility in terms of the overall strategic management to improve the company's financial and social performance and raise awareness of companies to conduct CSR activities.
\end{abstract}

Keyword: CSR, corporate social performance, corporate financial Pperformance, risk level, $R \& D$ intensity, size.

\section{PENDAHULUAN}

Tanggung jawab social/ Corporate Social Responsibility (CSR) menjadi tema yang relevan bagi perusahaan-perusahaan di seluruh dunia. CSR lahir dari desakan masyarakat atas perilaku perusahaan yang mengabaikan tanggung jawab sosial seperti perusakan lingkungan, eksploitasi sumber daya alam, dan penindasan kaum buruh. Inti dari konsep CSR adalah perhatian terhadap keberlanjutan (sustainability). Hal ini penting bagi keberhasilan dan kemampuan bertahan dalam jangka panjang. CSR menjadi hal yang dilematis karena adanya suatu dikotomi antara aktivitas CSR dan kinerja keuangan, di mana CSR sering dianggap pemborosan sehingga akan menurunkan kinerja keuangan, di sisi lain perusahaan terus dituntut untuk meningkatkan nilai para pemegang saham (Crowther dan Martinez, 2005).

Selain adanya tuntutan untuk mengimplementasikan kebijakan CSR, perusahaan, khususnya perusahaan publik juga dituntut untuk mengungkapkan apa yang telah dilakukan oleh perusahaan terkait kebijakan CSR tersebut dalam bentuk laporan tahunan atau pelaporan CSR secara terpisah. Jumlah informasi yang dimuat dalam laporan perusahaan dari waktu 


\section{Farah Margaretha}

ke waktu semakin meningkat, karena perusahaan juga semakin menyadari manfaat dari implementasi CSR dan peningkatan transparansinya (Aras dan Crowther, 2008).

Ada berbagai macam metode untuk meneliti pengaruh CSR terhadap nilai perusahaan/kinerja keuangan, maka cara penilaian masing-masing peneliti terhadap CSR dan kinerja keuangan berbeda-beda. Penilaian CSR berasal dari rating masing-masing dimensi CSR (community and society, corporate governance, employees, environment, customer and human rights) sebagai variabel yang terpisah (Makni et al., 2009). Menurut Indeks Sustainable and Responsible Investment - Keanekaragaman Hayati Indonesia (selanjutnya ditulis SRI-KEHATI), CSR bisa diukur menggunakan dimensi yang berbeda yaitu, environmental, community, corporate governance, human rights, business behavior, dan labor practice and decent work. Menurut (Aras et al., 2010) CSR bisa diukur menggunakan environment, energy, products or consumers, community involvement, employee health and safety, employee other, dan general.

Menurut Montabon et al., yang dikutip oleh Aras et al (2010), Montabon menyatakan bahwa ada pengaruh yang positif dan signifikan antara CSR dan kinerja keuangan. Dimana penelitian tersebut berdasarkan dari perspektif Environmental Management Practices (EMPs). Penelitian lain mengatakan bahwa semakin tinggi nilai dari CSR mengakibatkan kenaikan pada kinerja keuangan (Makni et al., 2009). Dimana faktor-faktor yang mempengaruhi CSR adalah community and society, corporate governance, employees, environment, dan customer and human rights, sedangkan faktor yang mempengaruhi kinerja keuangan adalah ROA, ROE, dan ROS (Makni et al., 2009). CSR dapat pula diukur dengan CSR disclosure, dimana hal yang menjadi perhitungan adalah society, product, customer, dan labor, tapi tanpa memperhitungkan environment (Mirfalzi, 2008). Berdasarkan latar belakang di atas maka tujuan penelitian ini adalah untuk menganalisis pengaruh antara tanggung jawab sosial perusahaan terhadap kinerja keuangan di Indeks SRI KEHATI.

\section{LANDASAN TEORI DAN PENGEMBANGAN HIPOTESA}

Waddock \& Graves (1997) memperkenalkan dua teori yang mendasar. Good management theory dan slack resource theory. Good management theory memfokuskan pada kinerja sosial (CSR), sedangkan slack resource theory menitikberatkan pada kinerja perusahaan terlebih dahulu.

Slack resource theory merupakan suatu teori di mana perusahaan harus mempunyai posisi keuangan yang baik untuk memberikan kontribusi pada kinerja sosial perusahaan. Kinerja sosial membutuhkan dana sehingga kinerja keuangan harus diperhatikan terlebih dahulu. 
Sedangkan good management theory merupakan suatu teori di mana suatu perusahaan mendapat reputasi baik dari stakeholders seiring dengan kinerja sosial yang dilakukan perusahaan, yang hal ini akan membuat perusahaan lebih mudah untuk mendapatkan posisi keuangan yang baik pula, sehingga kinerja sosial perusahaan merupakan hal yang perlu diperhatikan terlebih dahulu dibandingkan dengan kinerja keuangan perusahaan.

Berdasarkan slack resource theory, sebuah perusahaan harus memiliki posisi keuangan yang baik untuk berkontribusi pada kinerja sosial perusahaan. Melakukan kinerja sosial membutuhkan dana yang dihasilkan dari keberhasilan kinerja kevangan. Slack resource theory menyatakan bahwa kinerja keuangan yang lebih baik terjadi karena adanya ketersediaan slack resource (bisa berupa sumber daya keuangan ataupun yang lain) yang memberikan kesempatan bagi perusahaan untuk berinvestasi dalam aktivitas-aktivitas tanggung jawab sosial. Dengan kata lain kinerja keuangan yang lebih baik dapat menjadi alat yang tepat untuk memprediksi kinerja sosial yang lebih baik pula.

Waddock \& Graves (1997) menggunakan return on assets sebagai rasio profitabilitas menemukan hubungan yang positif dan signifikan antara kinerja keuangan perusahaan pada tahun sebelumnya dan kinerja sosial perusahaan saat ini.

Dari kerangka pemikiran tersebut hipotesa yang akan diuji adalah :

\section{$H_{1}$ : Kinerja Keuangan yang lebih baik akan berakibat pada meningkatnya CSR perusahaan di Indeks SRI-KEHATI}

Dalam penelitiannya Makni et. al. (2009) menemukan ada pengaruh yang signifikan antara CSR terhadap kinerja keuangan, dimana kinerja keuangan diukur dengan price to earning ratio. Dalam penelitiannya pula Makni et. al. (2009) mengatakan bahwa dengan meningkatnya CSR yang mengakibatkan menurunnya kinerja keuangan, maka akan terjadi siklus berkelanjutan dari pengaruh negatif tersebut. Namun, dalam penelitiannya Choi et. al. (2010) menemukan bahwa terdapat pengaruh yang positif dan signifikan antara CSR terhadap kinerja keuangan, serta penelitian tersebut menunjukkan bahwa pengaruh positif dan signifikan antara CSR terhadap kinerja keuangan ini terjadi saat perusahaan memprioritaskan CSR pada kepentingan pribadi pemegang saham. Hull dan Rothernberg (2008) menemukan bahwa terdapat pengaruh positif antara CSR terhadap kinerja keuangan dengan adanya inovasi sebagai variabel moderating untuk kedua variabel tersebut, karena dengan adanya inovasi maka perusahaan dapat mengkombinasikan kegiatan CSR dengan inovasi perusahaan yang berujung pada meningkatnya kinerja 


\section{Farah Margaretha}

keuangan. Dalam penelitiannya Aras et al (2010) menemukan bahwa dengan meningkatnya CSR belum tentu akan meningkatkan kinerja keuangan. Namun, terdapat pengaruh yang signifikan antara firm size terhadap CSR. Sehingga hipotesa yang dihasilkan adalah:

\section{$\mathrm{H}_{2}$ : $\quad$ Meningkatnya CSR menyebabkan meningkatnya kinerja keuangan perusahaan di Indeks SRI-KEHATI}

Salah satu aspek penting dari CSR dan kinerja keuangan adalah arah dari kausalitas. Waddock dan Graves (1997) mempelajari hubungan empiris antara kinerja keuangan dan sosial dan menemukan bahwa CSR positif dengan kinerja keuangan sebelumnya. hasilnya adalah sesuai dengan slack resource theory yang mendukung teori mereka yang hasilnya kinerja keuangan yang lebih baik membuat perusahaan berinvestasi di bidang yang terkait dengan domain sosial. Hasil ini juga didukung oleh good management theory yang menyatakan bahwa praktek-praktek manajemen yang baik dihasilkan dari keterlibatan dalam domain sosial untuk memperbaiki hubungan dengan pemangku kepentingan menyebabkan kinerja keuangan yang lebih baik. McWilliams dan Siegel (2000) mengemukakan argumen bahwa studi yang menganalisis hubungan antara tanggung jawab sosial dan kinerja keuangan spesifik dan menemukan arah yang signifikan dalam hubungannya jika mereka mengendalikan intensitas penelitian pengembangan ( $R$ \& $D)$ perusahaan yang merupakan faktor penting dari kinerja perusahaan. mereka menyimpulkan bahwa CSR memiliki efek terhadap kinerja diukur dengan profitabilitas ketika intensitas variabel penelitian dan pengembangan dimasukkan dalam model. Mereka berpendapat bahwa ini terjadi karena adanya korelasi kuat antara CSR dan R \& D.. D'Arcimoles dan Trebuca (2002) mendeteksi adanya hubungan yang positif dan signifikan antara intensitas R \& D dan kinerja keuangan dan membenarkan adanya hubungan antara CSR dan kinerja keuangan. Dengan demikian, hipotesis yang dapat dirumuskan adalah

Menurut Aras et. al. (2010) ada pengaruh antara CSR terhadap kinerja keuangan, hal ini bisa terjadi saat $R \& D$ intensity diperhitungkan dalam model. Dalam penelitiannya Aras et. al. (2010) mengatakan bahwa pengaruh yang terjadi antara CSR dan R\&D intensity karena diantara kedua variabel tersebut memiliki korelasi yang baik. Menurut Waddock dan Graves (1997) mengatakan bahwa R\&D intensity antara setiap perusahaan akan berbeda, maka akan mengakibatkan hasil yang berbeda pula. Oleh karena itu, maka hipotesa yang dihasilkan adalah:

\section{$\mathrm{H}_{3}$ : $\quad$ Terdapat pengaruh antara CSR terhadap kinerja keuangan perusahaan di Indeks SRI- KEHATI.}




\section{METODE PENELITIAN}

Populasi dalam penelitian ini adalah perusahaan yang terdaftar di index SRI KEHATI BEI. Penelitian ini menggunakan annual report serta laporan keuangan perusahaan sebagai sampel. Penelitian ini mengambil data keuangan perusahan tahun 2008 dan 2010 dan data CSR perusahaan yang berasal dari laporan tahunan tahun 2009. Metode yang digunakan purposive sampling.

Penelitian ini menggunakan data keuangan 2008 sebagai bagian dari analisis dimana CSR adalah variabel dependen. Untuk bagian dari analisis, di mana kinerja keuangan adalah variabel dependen, digunakan profitabilitas PER (Market Price Perusahaan dibagi dengan EPS) pada tahun 2010. Metode yang digunakan dalam mengukur kinerja sosial dalam laporan tahunan yaitu dengan metode content analysis.

Content analysis method dilakukan dengan cara melihat, memeriksa, mengecek, dan menghitung secara manual dimensi CSR (environment, energy, products or consumers, community, employee health and safety, employee other, dan general) dalam masingmasing laporan keuangan perusahaan menggunakan yes or no approach. Masing-masing dimensi CSR (environment, energy, products or consumers, community, employee health and safety, employee other, dan general) yang terdiri dari beberapa sub dimensi diberi nilai 1 (yes), apabila dalam laporan keuangan perusahaan dinyatakan bahwa perusahaan tersebut menaruh perhatian terhadap setiap sub dimensi CSR tersebut diatas, apabila sub dimensi tersebut diatas tidak ada maka akan diberi nilai 0 (no) (Mirfalzi, 2008). Dalam penelitiannya Khan (2010) melakukan hal yang sama dalam melakukan CSR disclosure. Namun, Khan (2010) menambahkan bahwa, masing-masing nilai dari sub-dimensi CSR akan dijumlahkan $\left(d_{i}\right)$ kemudian dibagi dengan nilai total $\operatorname{CSR}$ disclosure $\left(n_{j}\right)$, berdasarkan lampiran 10 dapat dilihat bahwa dalam penelitian ini ada Sembilan puluh total CSR disclosure, sehingga setiap nilai total CSR disclosure akan dibagi dengan sembilan puluh.

Dalam penelitian ini, menggunakan variabel kontrol yaitu ukuran perusahaan, yang menggunakan proksi log total asset. Variarbel kontrol lain yang digunakan adalah resiko. Dalam rangka pengendalian risiko D'Arcimoles dan Trebuca (2002) menggunakan rasio utang terhadap total asset. Selain dari variable control tersebut, juga digunakan R\&D intensitas sebagai variable control. Ukuran/rumus yang digunakan adalah pengeluaran untuk Research \& Development dibagi dengan penjualan.

\section{METODE ANALISIS DATA}




\section{Farah Margaretha}

Analisis dilakukan untuk melihat pengaruh CSR terhadap kinerja keuangan dan sebaliknya. Kinerja keuangan diukur menggunakan PER dan CSR diukur menggunakan environment, energy, products or consumers, community involvement, employee health and safety, employee other, dan general. Dalam hal ini metode statistik yang digunakan adalah Regresi Linear Berganda stepwise method.

Dalam stepwise method variabel yang masuk dalam model adalah variabel yang memiliki korelasi parsial yang paling besar (Priyatno, 2009). Priyatno (2009) juga mengatakan bahwa jika signifikansi variabel independen yang akan diuji kurang dari atau sama dengan kriteria seleksi tertentu, misalnya 0.05 atau 0.10 maka variabel tersebut akan dimasukkan kedalam model prediksi. Apabila tidak ada satupun variabel yang memenuhi kriteria seleksi maka variabel tidak akan masuk kedalam model. Persamaan Regresi yang akan di gunakan dalam penelitian ini adalah:

Model 1: Persamaan Regresi dengan perhitungan CSR

Model 2: Persamaan Regresi dengan perhitungan kinerja keuangan

Kinerja Keuangan $=\beta_{0}+\beta$ (CSR)

Model 3: Persamaan Regresi dengan perhitungan kinerja keuangan

Kinerja Keuangan $=\beta_{0}+\beta(C S R)$

Dalam penelitian ini seharusnya ada tiga model penelitian, yaitu saat kinerja keuangan mempengaruhi CSR dengan size, asset, dan risk level sebagai variabel kontrol, CSR mempengaruhi kinerja keuangan dengan size, asset, dan risk level sebagai variabel kontrol, dan CSR mempengaruhi kinerja keuangan dengan size, asset, risk level, dan R\&D intensity sebagai variabel kontrol. Namun, pada saat dilakukan pengujian ada beberapa model yang tidak bisa menghasilkan persamaan regresi, karena model-model tersebut tidak memenuhi kriteria seleksi dalam stepwise method. Model yang tidak bisa menghasilkan persamaan regresi adalah model satu yaitu saat kinerja keuangan mempengaruhi CSR dengan size, asset, dan risk level sebagai variabel kontrol.

\section{HASIL DAN PEMBAHASAN}

\section{Deskripsi Unit Analisis}

Penelitian ini menggunakan data keuangan dari tahun 2008 hingga tahun 2010 pada industri yang tercatat di Indeks SRI-KEHATI, serta memiliki data laporan keuangan dan sustainability report yang lengkap selama periode penelitian. Dan perusahaan yang memiliki R\&D expenditure dalam laporan keuangannya. Dari kriteria diatas, maka yang dijadikan objek penelitian adalah dua puluh tiga perusahaan untuk kriteria yang memiliki laporan keuangan dan sustainability report. 
Tabel 1

Hasil Perhitungan CSR disclosure Perusahaan yang Terdaftar dalam Indeks SRI-KEHATI

\begin{tabular}{|r|l|l|r|r|r|}
\hline \multicolumn{1}{|c|}{ No. } & Kodusahaan & \multicolumn{1}{c|}{$\boldsymbol{d}_{\boldsymbol{i}}$} & \multicolumn{1}{c|}{$\boldsymbol{n}_{\boldsymbol{j}}$} & \multicolumn{1}{c|}{ CSR } \\
\hline 1 & AALI & PT Astra Agro Lestari Tbk & 13 & 90 & 0.1444 \\
\hline 2 & AKRA & PT AKR Corporindo Tbk & 14 & 90 & 0.1556 \\
\hline 3 & ANTM & PT Aneka Tambang Tbk & 38 & 90 & 0.4222 \\
\hline 4 & ASII & PT Astra Internasional Tbk & 30 & 90 & 0.3333 \\
\hline 5 & BBCA & PT Bank Central Asia Tbk & 12 & 90 & 0.1333 \\
\hline 6 & BBRI & PT Bank Rakyat Indonesia Persero Tbk & 13 & 90 & 0.1444 \\
\hline 7 & BDMN & PT Bank Danamon Indonesia Tbk & 9 & 90 & 0.1000 \\
\hline 8 & BLTA & PT Berlian Laju Tanker Tbk & 12 & 90 & 0.1333 \\
\hline 9 & BMRI & PT Bank Mandiri (Persero) Tbk & 12 & 90 & 0.1333 \\
\hline 10 & INDF & PT Indofood Sukses Makmur Tbk & 10 & 90 & 0.1111 \\
\hline 11 & INTP & PT Indocement Tunggal Prakarsa Tbk & 9 & 90 & 0.1000 \\
\hline 12 & ISAT & PT Indosat Tbk & 29 & 90 & 0.3222 \\
\hline 13 & KLBF & PT Kalbe Farma Tbk & 6 & 90 & 0.0667 \\
\hline 14 & LPKR & PT Lippo Karawaci Tbk & 9 & 90 & 0.1000 \\
\hline 15 & MEDC & PT Medco Energi International Tbk & 30 & 90 & 0.3333 \\
\hline 16 & PGAS & PT Perusahaan Gas Negara Persero Tbk & 11 & 90 & 0.1222 \\
\hline 17 & PNBN & PT Bank Pan Indonesia Tbk & 9 & 90 & 0.0667 \\
\hline 18 & PTBA & PT Tambang Batubara Bukit Asam Tbk & 21 & 90 & 0.2333 \\
\hline 19 & SMCB & PT Holcim Indonesia Tbk & 32 & 90 & 0.3556 \\
\hline 20 & TINS & PT Timah Tbk & 35 & 90 & 0.3889 \\
\hline 21 & TLKM & PT Telekomunikasi Indonesia Tbk & 9 & 90 & 0.1000 \\
\hline 22 & UNTR & PT United Tractors Tbk & 16 & 90 & 0.1778 \\
\hline 23 & UNVR & PT Unilever Indonesia Tbk & 90 & 0.3111 \\
\hline
\end{tabular}

Tabel 1 merupakan hasil perhitungan dari CSR disclosure pada perusahaan di Indonesia yang terdaftar dalam Indeks SRI-KEHATI, jumlah keseluruhan dari item CSR disclosure ini ada sembilan puluh $\left(n_{j}\right)$, dimana nilai CSR didapati dari jumlah sub-dimensi CSR $\left(d_{i}\right)$ dibagi dengan total CSR disclosure $\left(n_{j}\right)$. Dari total duapuluh tiga perusahaan hanya lima buah perusahaan yang mendapatkan poin diatas tiga puluh persen, yaitu PT Aneka Tambang Tbk, PT Astra Internasional Tbk, PT Medco Energi International Tbk, PT Holcim Indonesia Tbk, dan PT Timah Tbk. PT Unilever Indonesia Tbk, PT Tambang Batubara Bukit Asam Tbk, PT Indosat Tbk memiliki nilai CSR disclosure yang berkisar di angka dua puluh persen. Sedangkan sisanya PT Astra Agro Lestari Tbk, PT AKR Corporindo Tbk, PT Bank Central Asia Tbk, PT Bank Rakyat Indonesia Persero Tbk, PT Bank Danamon Indonesia Tbk, PT Berlian Laju Tanker Tbk, PT Bank Mandiri (Persero) Tbk, PT Indofood Sukses Makmur Tbk, PT Indocement Tunggal Prakarsa Tbk, PT Kalbe Farma Tbk, PT Lippo Karawaci Tbk, PT Perusahaan Gas Negara Persero Tbk, PT Bank Pan Indonesia Tbk, PT Telekomunikasi Indonesia Tbk, dan PT 


\section{Farah Margaretha}

United Tractors Tbk memiliki nilai CSR disclosure berkisar dari enam hingga enam belas persen. Nilai CSR disclosure yang terbilang cukup rendah ini terjadi karena perusahaanperusahaan di Indonesia dalam menjalankan kegiatan CSR masih berpusat pada community development. Sedangkan pada kenyataannya community development merupakan bagian kecil dari CSR (Kartini, 2009).

Tabel 2 merupakan hasil analisis statistik deskriptif untuk perusahaan yang terdaftar dalam Indeks SRI-KEHATI, dapat dilihat bahwa kinerja keuangan diukur dengan PER sebagai indikatornya.

\section{Tabel 2}

\section{Statistik Deskriptif}

23 Perusahaan yang Terdaftar di Indeks SRI-KEHATI

\begin{tabular}{|l|r|r|r|r|}
\hline & \multicolumn{1}{|c|}{ Minimum } & \multicolumn{1}{c|}{ Maksimum } & \multicolumn{1}{c|}{ Rata-Rata } & \multicolumn{1}{c|}{ Standar Deviasi } \\
\hline PER08 & 8.32 & 65.59 & 24.4643 & 12.61597 \\
\hline PER10 & 4.65 & 53.79 & 21.5917 & 13.08642 \\
\hline RISK08 & .2306 & .9083 & .578174 & .2257340 \\
\hline RISK09 & .1815 & .9148 & .579052 & .2370730 \\
\hline ASSET08 & 15.18 & 30.66 & 22.2922 & 5.80350 \\
\hline ASSET09 & 11.30 & 30.87 & 20.6617 & 5.79349 \\
\hline SALES08 & 15.14 & 29.81 & 22.0787 & 5.47747 \\
\hline SALES09 & 11.48 & 30.18 & 20.5391 & 5.56671 \\
\hline CSR09 & 0.0667 & 0.4222 & 0.195161 & 0.1136460 \\
\hline RD09 & .000029 & .009226 & .00281533 & .004141600 \\
\hline
\end{tabular}

\section{Pembahasan}

Pembahasan ini menjelaskan hasil dari pengujian terhadap variabel-variabel yang ada dalam model. Tabel 3 diketahui bahwa nilai sigifikansi pengujian dengan CSR sebagai variabel independen dan kinerja keuangan sebagai variabel dependen adalah sebesar 0.048. Berdasarkan pengujian yang dilakukan tersebut, maka didapatkan hasil bahwa variabel CSR berpengaruh positif dan signifikan terhadap variabel kinerja keuangan. Sedangkan pada variabel lainnya (risk level, asset, dan sales) tidak ditemukan pengaruh apapun, hal ini dikarenakan variabel tersebut diatas adalah variabel yang tidak dimasukkan dalam model. Hal ini disebabkan karena variabel-variabel tersebut diatas tidak bisa memenuhi kriteria seleksi dalam stepwise method. Pengaruh yang positif dan signifikan ini menandakan bahwa setiap tejadi kenaikan CSR dari perusahaan maka akan terjadi kenaikan kinerja keuangan. 
Tabel 3

Hasil uji † dan $\mathbf{R}^{2}$

\begin{tabular}{|l|c|c|c|c|c|}
\hline NO. & $\begin{array}{c}\text { VARIABEL } \\
\text { DEPENDENT }\end{array}$ & $\begin{array}{c}\text { VARIABEL } \\
\text { INDEPENDENT }\end{array}$ & SIG. & $\begin{array}{c}\text { KOEFISIEN } \\
\text { BETA }\end{array}$ & $\mathrm{R}^{2}$ \\
\hline 1. & CSR & $\begin{array}{c}\text { Kinerja } \\
\text { Kevangan }\end{array}$ & - & - & - \\
\hline 2. & Kinerja Kevangan & CSR & 0.048 & 48.009 & 0.868 \\
\hline 3. & Kinerja Kevangan & CSR & 0.007 & 116.887 & 0.174 \\
\hline
\end{tabular}

Berdasarkan hasil perhitungan yang terdapat di tabel 3 (Hasil Uji Regresi Model 3). Diketahui bahwa nilai sigifikansi pengujian dengan kinerja keuangan sebagai variabel dependen dan CSR sebagai variabel independen adalah sebesar 0.007, dapat dilihat bahwa variabel CSR berpengaruh positif dan signifikan terhadap model perhitungan diatas. Sedangkan pada variabel yang lain (risk level, R\&D intensity, asset, dan sales) tidak dapat ditemukan pengaruh yang signifikan terhadap model. Karena metode yang digunakan adalah stepwise maka variabel tersebut diatas adalah variabel yang tidak dimasukkan dalam model. Hal ini disebabkan karena variabel-variabel tersebut diatas tidak bisa memenuhi kriteria seleksi dalam stepwise method.

Kedua hasil perhitungan baik dalam model 2 maupun model 3 menandakan dengan meningkatnya CSR maka akan terjadi peningkatan kinerja keuangan. Hal ini sama dengan perhitungan Waddock dan Graves (1997), dimana dalam penelitiannya Waddock dan Graves menemukan adanya pengaruh yang signifikan dan positif antara CSR terhadap kinerja keuangan. Menurut McGuire et. al. yang dikutip oleh Balabanis et. al. (1998), adanya pengaruh yang positif antara CSR dan kinerja keuangan karena perusahaan yang mempunyai nilai CSR lebih tinggi akan jarang menghadapi masalah pekerja, dan konsumen lebih menyukai produknya. Kemudian Balabanis et. al. (1998) mengatakan bahwa CSR akan meningkatkan reputasi perusahaan serta hubungan dengan bank, investor, dan pemerintah. Dengan meningkatnya hubungan terhadap ketiga institusi tersebut, dapat dikatakan bahwa perusahaan akan mendapatkan keuntungan ekonomis.

Dalam penelitiannya Aras et. al. (2010), menemukan adanya pengaruh yang signifikan antara size terhadap CSR dan tidak menemukan adanya pengaruh yang signifikan antara CSR dan kinerja keuangan. Makni et. al. (2008) menemukan adanya pengaruh yang 


\section{Farah Margaretha}

signifikan dan negatif antara CSR dan kinerja keuangan. Ditemukan pengaruh yang negatif antara CSR dan kinerja keuangan karena dengan adanya CSR di perusahaan mengakibatkan perusahaan harus mengeluarkan biaya tambahan dalam kegiatan operasionalnya (Balabanis et. al., 1998). Adanya biaya tambahan dalam kegiatan operasional perusahaan dapat dikatakan membuat perusahaan yang bersangkutan berada dalam posisi yang tidak ekonomis. Menurut Kartini (2009) pada awalnya memang CSR akan menimbulkan biaya tambahan bagi perusahaan, namun dalam jangka waktu yang panjang, kinerja keuangan perusahaan yang menerapkan CSR akan mengalami peningkatan (Kartini, 2009). Dalam penelitian Waddock dan Graves (1997), Waddock dan Graves menemukan adanya pengaruh yang signifikan dan positif antara CSR terhadap kinerja keuangan. Dalam penelitianya Choi et. al. (2010) menemukan bahwa CSR dan kinerja keuangan memiliki pengaruh yang signifikan dan positif saat perusahaan memprioritaskan kepentingan stakeholder.

\section{PENUTUP}

Berdasarkan hasil analisis dan pembahasan, dapat ditarik kesimpulan sebagai berikut:

1. CSR

a) CSR berpengaruh positif dan signifikan terhadap kinerja kevangan, dengan adanya R\&D intensity, risk level, asset, dan sales sebagai variabel kontrol. Dimana variabel yang dikeluarkan dalam perhitungan adalah risk level, R\&D intensity, asset, dan sales.

b) CSR berpengaruh positif dan signifikan terhadap kinerja keuangan, dengan adanya risk level, asset, dan sales sebagai variabel kontrol. Dimana variabel yang dikeluarkan dalam perhitungan adalah risk level, asset, dan sales.

2. Kinerja keuangan

Tidak ditemukan pengaruh apapun antara kinerja keuangan terhadap CSR. Hal ini dikarenakan dalam model ini, tidak ada satu variabel independen dan variabel kontrol yang bisa mempengaruhi CSR.

Hasil penelitian ini diharapkan dapat diterapkan oleh manajer keuangan perusahaan dan pemerintah. Adapun implikasi manajerial dari penelitian ini adalah sebagai berikut:

1. Manajer keuangan perlu mempertimbangkan CSR untuk menjadi bagian dari kegiatan operasional perusahaan. Hal ini ditunjukkan dengan adanya pengaruh yang signifikan dan positif antara CSR terhadap kinerja keuangan perusahaan.

2. Kepada perusahaan di Indonesia yang hendak melakukan CSR sebaiknya tidak hanya fokus terhadap community development saja, karena dimensi-dimensi CSR tidak hanya community development tetapi juga ada environmental, corporate governance, 
human rights, business behavior, dan labor practice and decent work. Kebanyakan perusahaan di Indonesia dalam melakukan CSR masih fokus pada community development sedangkan dimensi CSR yang lainnya seolah terlupakan.

3. Kepada pemerintah sebaiknya memberikan regulasi dan aturan hukum yang jelas terhadap penetapan CSR di Indonesia. Selain itu, sebaiknya pemerintah juga mendirikan sebuah badan independen penilaian CSR yang akan menilai besarnya CSR dari masing-masing perusahaan yang ada di Indonesia. Sehingga, nilai dari CSR (CSR disclosure) sudah ada ketetapannya, karena dalam melakukan CSR disclosure, setiap peneliti pasti mempunyai penilaian yang berbeda-beda, sehingga hasil dari penelitian mungkin akan memberikan pengaruh yang tidak signifikan.

\section{DAFTAR PUSTAKA}

Abbott, W.F. and Monsen, R.J. (1979), "On The Measurement of Corporate Social Responsibility: Self-reported Disclosures as a Method of Measuring Corporate Social Involvement", The Academy of Management Journal, Vol. 22 No. 3: 501-15.

Anderson, J.C., and A.W. Frankle. 1980. Voluntary Social Reporting: An Iso Beta Portfolio Analysis. The Accounting Review, 55: 467-479.

Aras, Guler.; Aybars, Ash. \& Kutlu, Ozlem. (2010). Managing Corporate Performance: Investigating the Relationship Between Corporate Social Responsibility and Financial Performance in Emerging Markets, International Journal Of Productivity And Performance Management. 229-255.

Aras, Guler. and Crowther, D. (2008), "Corporate Sustainability Reporting: a Study in Disingenuity?", Journal of Business Ethics, Vol. 87 No. 1. 279-89.

Aupperle, K. E., A. B. Carroll dan J. D. Hatfield.1985. An Empirical Examination of the Relationship Between Corporate Social Responsibility and Profitability. Academy of Management Journal, 28 (2): 446-463.

Balabanis, George.; Phillips, Hugh C. \& Lyall, Jonathan. (1998). Corporate Social Responsibility and Economic Performance in The Top British Companies: Are They Linked? European Business Review. 25-44.

Belkoui, A. and Karpik, P.G. (1989), "Determinants of The Corporate Decision to Disclose Social Information", Accounting, Auditing \& Accountability Journal, Vol. 2 No. 1: 36-51.

Choi, Jong-Seo.; Kwak, Young-Min. \& Choe, Chongwoo. (2010). Corporate Social Responsibility and Corporate Financial Performance: Evidence from Korea. Munich Personal RePEC Archive. 1-10

Crowther, David and E.O. Martinez. (2007), Current debates in corporate social responsibility: An agenda for research. Issues in Social and Environmental Accounting 1 (1): $26-39$.

D'Arcimoles, C.H. and Trebucq, S. (2002), "The Corporate Social Performance - Financial Performance Link: Evidence from France", Working Paper Series.

Folger, H. R., and F. A. Nutt. (1975), A Note on Social Responsibility and Stock Valuation. Academy of Management Journal, 18: 155-159. 


\section{Farah Margaretha}

Hull, Clyde Eir'lkur. and Rothenberg, Sandra. (2008). Research Notes and Commentaries Firm Performance: The Interactions of Corporate Social Performance With Innovation And Industry Differentiation. Strategic Management Journal. 781-789.

Kartini, Dwi. (2009). Corporate Social Responsibility, Transformasi Konsep Sustainability Management dan Implementsi di Indonesia. Bandung: PT Refika Aditama.

Khan, Md. Habib-Uz-Zaman. (2010). The Effect of Corporate Governance Elements on Corporate Social Responsibility Reporting: Empirical Evidence from Private Commercial Banks of Bangladesh. International Journal of Law and Management. 82-109

Makni, Rim.; Francoeur, Claude. ang Bellavance, Francois. (2009). Causality Between Corporate Social Performance And Financial Performance: Evidence From Canadian Firm, Journal Of Business Ethics. 409-412.

McGuire, J.B., Sundgren, A. and Schneeweis, T. (1988), "Corporate Social Responsibility and Firm Financial Performance", The Academy of Management Journal, Vol. 31 No.4: 854-72.

McWilliams, A. and Siegel, D. (2000), "Corporate Social Responsibility and Financial Performance: Correlation or Misspecification?", Strategic Management Journal, Vol. 21 No. 5: 603-9.

Mirfalzi, Edwin (2008). Corporate Social Responsibility (CSR) Information Disclosure by Annual Reports of Public Companies Listed at Indonesia Stock Exchange (IDX), International Journals of Islamic and Middle Eastern Finance and Management. 275-284

Orlitzky, M,; Schmidt, Frank L. \& Rynes, Sara L. (2003). Corporate Social and Financial Performance: a Meta-Analysis. Organizational Studies. 403-441

Priyatno, Duwi. (2009). SPSS untuk Analisis Korelasi, Regresi, dan Multivariate. Penerbit Gava Medika.

Waddock, S.A. and Graves, S.B. (1997), "The Corporate Social Performance: Financial Performance Link", Strategic Management Journal, Vol. 18 No. 4: 303-19. 